\title{
Intercultural Impact From a Short-Term Study-Abroad Program
}

\section{in Thailand}

\section{Brad Deacon \\ Nanzan University \\ Kevin Ottoson \\ Nanzan University}

\section{Reference Data:}

Deacon, B., \& Ottoson, K. (2020). Intercultural impact from a short-term study-abroad program in Thailand. In P. Clements, A. Krause, \& R. Gentry (Eds.), Teacher efficacy, learner agency. Tokyo: JALT. https://doi.org/10.37546/JALTPCP2019-26

Recent government initiatives have helped increase the number of Japanese students studying abroad. However, our understanding of study abroad and intercultural development is largely informed by research in Western contexts. The purpose of this study was to uncover the key areas that students attribute to their intercultural competence growth and development during a short-term study-abroad program in Thailand. This paper offers findings from open-ended questionnaires that were given to 15 Japanese 2nd-year female university students before and after they participated in a three-week study abroad. Qualitative analysis of the pre-sojourn results primarily revealed health and safety concerns. These concerns were later shown to be mostly unrealized in post-sojourn findings analysis that instead emphasized the importance of students' psychological and self-fulfillment needs. The implications this research has for language teachers, program coordinators, and other stakeholders who aim to support students' intercultural development in short-term study-abroad programs are provided.

昨今の政府の取り組みにより、留学入行く日本の学生数は増加傾向にある。しかし、留学や異文化教育についての私たちの 理解は、西洋の文脈における研究から主に情報を得ていると言える。本研究の目的は、タイにおける3 週間の留学プログラム の間に、学生の異文化理解やその発達が主に何によってもたらされたのかを明らかにすることだった。参加した 15 名の女 子学生たち(大学 2 年生) に対して、留学の事前と事後に自由回答式の質問を与え、その調査結果をもとに明らかになったこと をここでは論じていく。事前調査における質的分析では、主に健康や安全面での懸念が明らかになった。これらの懸念は事後
調査での分析ではほとんど認められず、代わりに心理的な自己実現欲求が重要な側面であることがわかった。この研究におけ る示唆は、語学教員、留学コーディネーター、そしてその他、短期留学プログラムにおける学生の異文化教育を支援する関係 者に向けられる。

ntercultural competence has gained more attention in recent years as a key area to cultivate for more effective cross-cultural interaction (Deardorff, 2009). Moreover, study abroad is seen as an effective means for intercultural development (Deardorff, 2004). However, the impact of short-term study-abroad programs, especially on intercultural competence, is an understudied area (Czerwionka, Artamonova, \& Barbosa, 2015). Koyanagi (2018) suggested that an assumption of automatic internationalization through study abroad may explain the lack of research into Japanese short-term overseas programs. As Japanese participation in short-term overseas programs increases, understanding participants' experiences and the specific conditions that underpin their success is necessary for teachers to more effectively support students before, during, and after a sojourn. Currently, there is a limited understanding of the experiences of Japanese students studying abroad in Asia. Thus, in this paper we describe pre- and post-sojourn responses to a questionnaire that was designed to uncover the key factors to which students attribute their intercultural competence development during a short-term program in Thailand.

\section{Theoretical Framework}

A wealth of definitions and conceptualizations of intercultural competence can be found in the literature (see Spitzberg \& Chagnon, 2009). However, Deardorff's (2006) widely referenced and accepted definition - the "ability to communicate effectively and appropriately in intercultural situations based on one's intercultural knowledge, skills, and attitudes" (p. 249) - will be used in this study as it both connects to Deardorff's models explored below and also encapsulates our understanding of what is considered necessary to effectively bridge cultural differences. 
Developing intercultural competence, during a sojourn and in general, can be seen as a process, as evident from the models of Bennett $(1986,2013)$ and Deardorff $(2006$, 2009). Deardorff's $(2006,2009)$ process model (Figure 1 ) describes this lifelong process as beginning with the requisite attitudes of openness, curiosity, and respect. Situated at the beginning of the model, attitude represents a critical intercultural learning component.

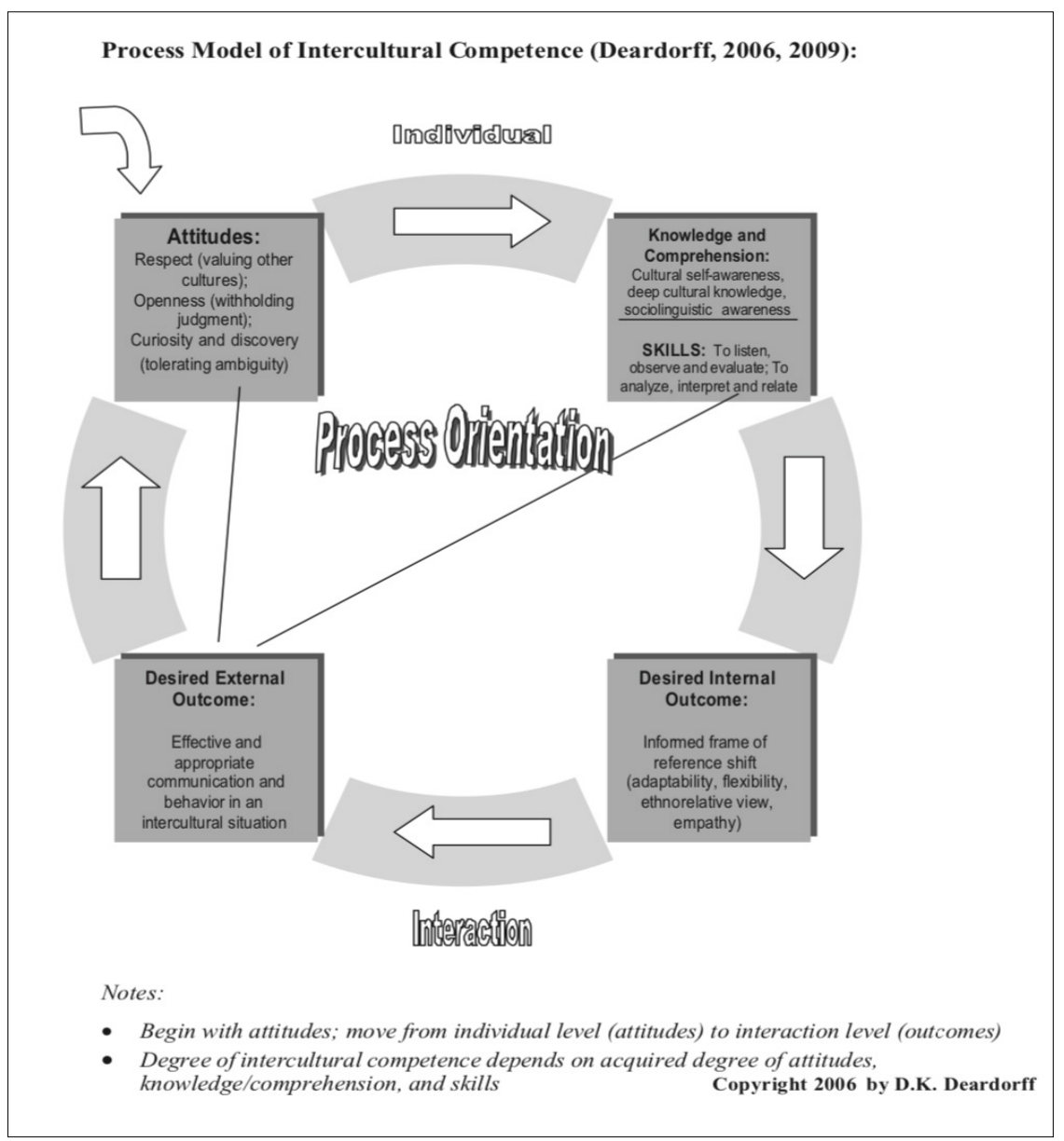

Figure 1. Process model of intercultural competence (Deardorff, 2006, 2009; used with permission from SAGE).
Study-abroad participants face several challenges when adapting to overseas environments, including safety, health, and socialization (see Tasci \& Ko, 2015). Threats to safety and health can produce both positive and negative responses in participants (Wingenbach, Chmielewski, Smith, Piña, \& Hamilton, 2006). Rodriguez and Roberts (2011) described how learning can be diminished in the face of concerns about health and safety. Maslow's (1943) hierarchy of needs (Figure 2) provides a useful framework within which these needs can be categorized in the study-abroad context. Lindsay (2014) used Maslow's framework to investigate male students' motivation for studying abroad and found it most closely associated with a desire to satisfy esteem and self-actualization needs. Tasci and Ko (2015) examined the motivational needs of a diverse range of participants in the overseas travel sector and found Maslow's top need of self-actualization not to be common for overseas participation. According to Maslow, human needs are categorized according to the following areas: (a) physiological, (b) safety and security, (c) love and belonging, (d) esteem, and (e) self-actualization. As people's initial needs, such as physiological and safety, are satisfied, they can progress up the pyramid to satisfy other needs. Maslow's theory is helpful both for reconceptualizing international education and study-abroad programs and also as a tool for understanding the important role of sojourners' safety and psychological needs specific to the success or failure of a program (Deardorff, 2016). This project adopted Maslow's theory as a framework within which to categorize participants' reflections and understand the conditions that encourage the development of intercultural competence. In particular, Maslow's theory was used to show how students' basic needs may give way to more complex needs over time.

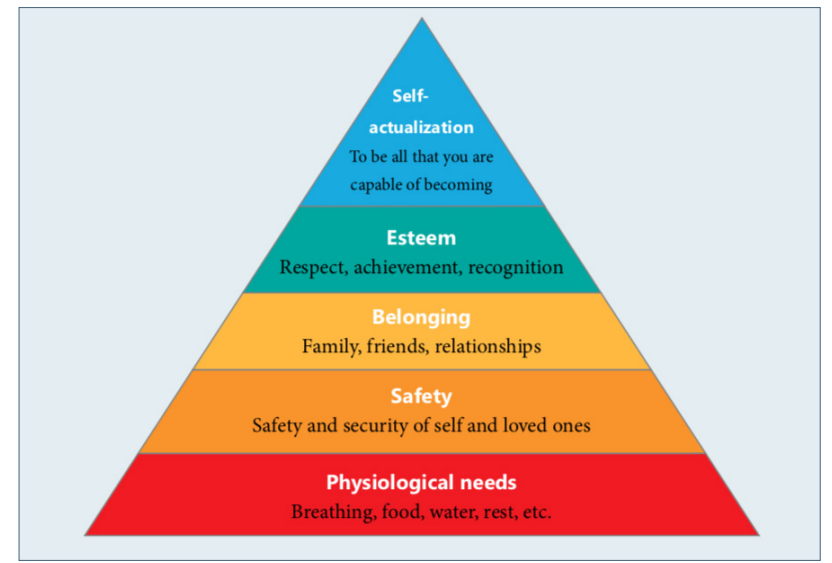

Figure 2. Maslow's hierarchy of needs (used with permission from Abax.). 


\section{Methodology}

This study is contextualized within the Nanzan Asia Program (NAP), which is a full-year academic credit program at Nanzan University. The study-abroad component spans 3 or 4 weeks depending on the destination. The NAP offers 2 nd-year students a choice of programs in seven countries within Asia. Students are required to participate in program-wide and country-specific lectures/workshops before their sojourn. In general, the main aims of the program are to help students develop fieldwork skills (and later give a presentation at both host and home universities based on fieldwork research) and cultivate language skills abroad.

Students in this study participated in the NAP at Khon Kaen University (KKU) in Khon Kaen, Thailand. The KKU program is a particularly popular NAP destination as it offers participating students the opportunity to be paired with a local KKU tutor-buddy-a term used to reflect the dual tutorial and friendship roles that KKU students serve. Hereinafter, the words tutor and buddy refer to these tutor-buddies. Specifically, the tutor-buddies support the Japanese students in several ways by providing structured Thai language tutoring following daily Thai language lessons, offering fieldwork assistance such as translating and administering research surveys to Thai locals, accompanying the students to weekly cultural events (e.g., sports, cooking, dance, and arts-and-crafts activities), offering guidance during overnight field excursions (e.g., elephant village, silk village, and temple visits), and in many cases, providing friendship. Appendix A includes a daily routine example.

The purpose of this study is to consider the impact of intercultural interactions on the group of Japanese university students $(\mathrm{N}=15)$ who participated in this 3-week program during August 2018. All participants were female, as no males chose to participate. In previous programs, the gender composition averaged 20 total students, comprising approximately 16 females and 4 males. All students participated voluntarily, and approval to conduct this research was given by the Nanzan ethics committee.

The following questions framed this qualitative study:

1. What were the experiences of the Japanese participants in the short-term study-abroad in Thailand?

2. What intercultural competence gains, if any, did the participants perceive after the program?

3. What intercultural competence developments were revealed through the participants' short-term program experience?
To address these questions and gain a better understanding of how the participants assessed their own intercultural development, open-ended questionnaires (see Appendix B) were given approximately a month before and after their sojourn. We analyzed the predata and postdata sets using thematic coding (Saldaña, 2013) and the research questions as a conceptual framework. We then discussed our analyses and found common agreed-upon themes. Later we reanalyzed the data to confirm the main themes. Finally, grounded theory (see Charmaz, 2014; Strauss \& Corbin, 1990) was used to conceptualize salient findings.

\section{Results}

The findings illuminated the development that students attributed to their experience and the intercultural situations that facilitated that development. Individual coding of participants' responses in the pre-sojourn survey led to the identification of the following themes: health and safety, curiosity, communication, and relationships (Figure 3).

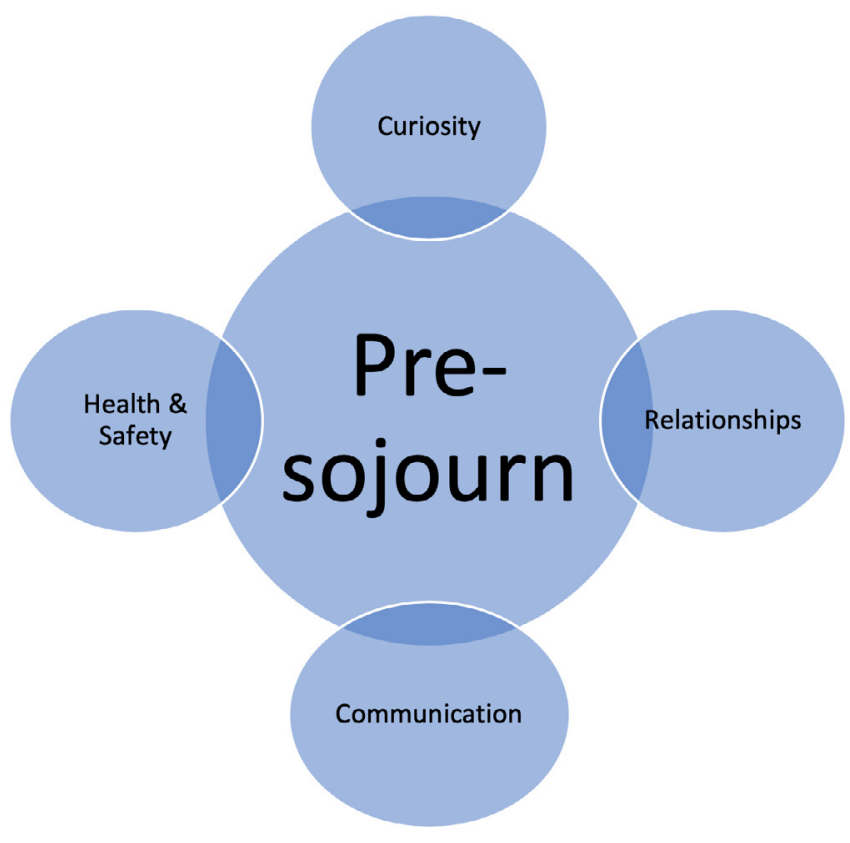

Figure 3. Pre-sojourn questionnaire themes. 
Next, individual coding of responses to the post-sojourn survey led to identification of the following overall themes: developing attitudes, health and safety concerns (unrealized), relationships, developing cultural self-awareness, and practical issues (Figure 4). This section provides several examples of participants' questionnaire responses that highlight each of these themes. Readers may notice overlapping of themes in some excerpts below. Although all responses did not always fit neatly into one thematic category, responses were coded according to the theme(s) within which they were situated.

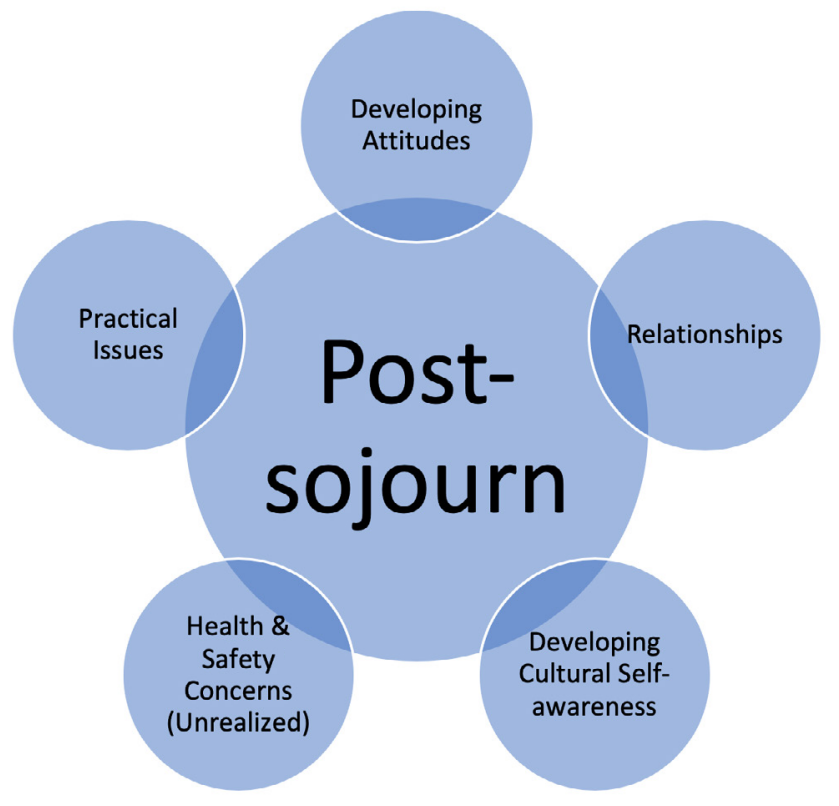

Figure 4. Post-sojourn questionnaire themes.

\section{Pre-Sojourn Themes}

Health and Safety

In the pre-sojourn questionnaire, comments focused primarily on concerns about health and safety, particularly staying healthy and avoiding discomfort. For instance, Participant 1 said, "One of my biggest concerns is cramps .... I will bring medicine which I usually use, but l'm worried about whether l'll be able to go to the hospital." In addition to health and insects, participants mentioned a concern over food and water, as in the following comment, "I have three concerns. One is food. I am not sure if I would like Thai food. Next is to get sick there, and last is the safety of the water and the number of insects"

(Participant 11). Safety concerns were also stated by several others, such as Participant 1.

$\mathrm{I}$ am concerned if my passport would be stolen in Thailand. I know Thailand is not a bad place, and some tutors are going to be with us. Yet, l'm worried someone will steal my stuff because I am a Japanese.

\section{Communication}

Beyond health and safety, participants also expressed concerns over their ability to communicate with the local student tutors in their program. Participant 2 noted her anxiety and worry as follows: "I'm really worried about whether I can communicate with tutors well. Because I seldom talk with foreigners, I'm very anxious." Further, Participant 13 noted a worry over the possibility of differences in communication styles.

The biggest worry $\mathrm{I}$ have is not being able to communicate well with the tutors. 1 do not know how much they can speak English or Japanese. In addition, the way they communicate may differ from Japan. I would like to actively speak and be good friends with them.

Not everyone voiced concerns over communication; for example, Participant 7 conveyed a more optimistic tone: "I would like to cherish the time socializing with the local people."

\section{Relationships}

Participants voiced optimism about developing relationships and friendships with their tutors in other ways in Thailand. The following comment from Participant 12 illustrates the importance she ascribed to foreign languages to facilitate the development of friendship with tutors: "I wish I can be friends with them, so I hope that I can learn English and Thai a lot there." Another comment from Participant 7 suggests that they had positive interactions and a desire to deepen that relationship: "The buddy who I am paired with now is very friendly [and contacted me through social media]. I am planning to deepen my relationships with my buddy and absorb more about Thai." In contrast to the more optimistic tone above, several students conveyed concerns about their ability to develop relationships with tutors. Participant 10 said, "[I am worried about] Whether 
I can become good friends with tutors," and Participant 7 voiced concern over her ability to be appropriate in her interactions: "I am worried about getting along with the tutors and the students there, and being able to communicate properly."

\section{Curiosity}

In addition to optimism about communicating and developing relationships with the local university students, participants professed curiosity towards the Thai tutors, as exemplified by Participant 5 who stated, "I want to make friends with the tutors. Since it will be my first time to study abroad, I hope I can know the culture and history of Thailand and get many great experiences there." Beyond a curiosity about tutors, Participant 5 also expressed curiosity about the culture of Thailand. This curiosity was evident in some of the other participants' responses, as follows:

My friend is an international student at Nanzan University. She told me a lot about Thai's culture and the ways of thinking in Thailand that I found very interesting for me .... Also, I would like to know how they live in the developing country (Participant 1).

Participants gained an interest in Thailand not only from international students but also from previous program participants, as can be seen in the following comment from Participant 12: "There is a senior student who has joined the program before and I found it [Thai culture] interesting after talking to her."

In summary, participants' pre-sojourn questionnaire comments revealed concerns over health and safety, effective and appropriate communication, and developing relationships. Moreover, the comments suggested curiosity about Thai culture in terms of its history, daily life, cultural attitudes, and beliefs. Participants also expressed a desire to develop positive relationships, especially with tutors.

\section{Post-Sojourn Themes}

In the post-sojourn questionnaire, participants' reflections demonstrated their developing attitudes of curiosity towards the lives of others, their ability to cultivate relationships, and their emerging intercultural knowledge. Similar to their pre-sojourn comments, several participants mentioned concerns largely to do with health and safety.

\section{Health and Safety}

Most concerns dealt with staying healthy and avoiding discomfort. One area of discomfort was in relation to food. Participant 13 mentioned this concern:

Before going to Thai, I was worried about not being able to eat spicy food, and getting stomach aches. However, I was able to adjust to the spiciness, and moreover, there were many kinds of taste and there were many delicious foods.

Despite their initial concerns, students conveyed a different tone afterwards. Participant 12 mentioned her unrealized concerns over safety and health, "Although I thought Thailand was not safe, people who lived there were kind. I worried about catching Dengue fever but it was ok while I was bitten by a mosquito." Participant 15 exemplified multiple themes as follows: "I was worried about the health, lifestyle and food before I went to Thailand, but there were no problems when I was there." These comments about health and safety suggest that students' concerns were either not realized or not as bad as they had anticipated.

\section{Relationships}

Before the sojourn, participants were also concerned about whether they could communicate and develop relationships. The next selection of comments highlights how participants were able to develop positive relationships, especially with tutors. According to Participant 10, "When communicating with our tutors, it was difficult to express my feelings because we have different languages and cultures. However, I found that we can get along by trying to communicate in each language." Participant 5 noted the importance of her tutor facilitating her ability to experience the culture in Thailand in these words: "More than anything, meeting with a tutor helped me to know and feel the culture and atmosphere. It was a good thing to meet the tutor for me."

In addition to mentioning relationships with tutors, participants commented on their relationships with their Japanese classmates. The following succinct comment from Participant 4 mentions how the support of her classmates allowed her to assist others: "I could help others with my friends." On the other hand, not everyone was able to develop positive relationships with their fellow participants, as the following comment illustrates.

I was worried about the relationship with the people who attend this NAP program too. I did not get along well with other people throughout this program .... I I felt isolated when we had to work as a group .... . and I could not get along with them because I do not have similar hobbies with them (Participant 1). 
Participants described their relationships with local university students as well as their peers from Japan. On the whole, comments showed that tutors and their Japanese group members helped participants to experience Thai culture and develop their knowledge about Thailand.

\section{Developing Attitudes}

As mentioned earlier, participants described how tutors and their classmates supported and allowed them to learn more about Thailand. Furthermore, participants' comments demonstrated an increase in curiosity about other cultures. A number of comments reflected participants' desire to learn languages, explore Asia, and show an openness to communicating cross-culturally. Participant 15 expressed a heightened desire to learn about other cultures and attain languages in the following comment: "This trip made me strongly wish to learn foreign languages and get to know foreign culture more." Participant 8 echoed this interest along with a regret about the program's brief duration: "Although I had been interested in western countries until now, I'm getting interested in Asia through this NAP. I think three weeks are too short. If it had been for a month, I could experience more." Another development came in participants' willingness to communicate with others. Participant 4 described a change in her ability to talk with strangers.

I think I changed. The reason why I think so is that I became able to talk to unknown people positively. When I was in trouble calling a taxi without my tutors, I could ask people around me which I couldn't do before.

\section{Developing Cultural Awareness}

Participants also described a heightened intercultural awareness during the program. The following excerpts report increased knowledge of Thai and Japanese culture.

Participant 4 showed an interest and ability to compare and contrast other ways of life with her own.

I learned Japanese original cultures which I thought were common in the world and I also learned Thai original ones through interactions with my tutors . . . . At night markets, I learned the usual lifestyles in Thailand .... in fact, I think my knowledge was spread after experiencing what we can't do in Japan.

Participant 12 noted the importance of tutors as facilitators of cultural awareness and knowledge building: "[What I learned was] comparing differences between Thai and
Japanese culture. In fact, I could get a lot of knowledge because my tutors always taught me knowledge about Thailand."

\section{Practical Issues}

Finally, when asked about what advice they would like to give to future participants, the students offered various practical tips.

When you pack your stuff, you should prepare Japanese food. Also, even if you think you are okay, you might get ill like having a headache, fever, or stomachache. It is important for you to prepare some medicine. Souvenirs from Japan will be needed because you will get along well with your tutor. (Participant 5)

Participant 8 further advised future participants to ask previous participants and tutors for advice: "Because Khon Kaen is not written on homepages, you should ask your seniors or tutors if you have some troubles. You should take extra antipyretic analgesic. You should prepare souvenirs which you can give to everyone." Many of the comments focused on bringing health-care items and food from Japan. However, the concerns about health, safety, communication, and relationships were mostly unrealized. The final comment from Participant 12 encapsulates the sentiment of the majority of these students: "I want to tell my juniors that most of your worries don't happen. Those who worry about food should take Japanese food."

In sum, participants' comments prior to going to Thailand highlighted concerns pertaining to anxiety about their health, safety, communication, and relationships, but post-sojourn comments underscored how their concerns were largely unrealized. Instead, participants reported the development of intercultural attitudes, knowledge, awareness, and skills. Some of the participants attributed this development to the positive relationships they had developed with both Thai tutors and fellow sojourners from Japan.

\section{Discussion}

The participants of this investigation reported development of intercultural attitudes, knowledge, awareness, and skills. Before departure, participants mainly focused on health and safety during their sojourn in Thailand. In contrast, a preoccupation with health and safety was mostly absent from post-sojourn questionnaire results. When this was mentioned, participants reported that their concerns were mostly unrealized or not as bad as originally assumed. Maslow's (1943) hierarchy of needs provides a model for 
understanding these responses. According to Maslow's theory, it is necessary that basic needs (e.g., food, water, rest, warmth, health, and safety) be met before any attention can be given to psychological and self-fulfillment needs. In the case of these participants, their psychological needs were shown to involve communicating with others and developing relationships, especially with Thai tutor-buddies.

Despite health and safety concerns being largely unrealized, when asked about what kind of advice they would give to future participants, the students addressed the basic needs of health and safety, such as suggesting that future participants bring Japanese food and medicine. They did not address higher-level needs of relationships and selffulfillment except to suggest bringing souvenirs to give to tutor-buddies. Further investigation, especially involving both male and female participants, is necessary to determine why participants chose to give advice on health and safety rather than interacting with the local population in Thailand. Maslow's (1943) theory suggests that if students can care for their health and safety, they will then be able to more freely focus on developing the attitudes, knowledge, and skills that Deardorff's $(2006,2009)$ model deems necessary for developing intercultural competence. Figure 5 provides a conceptualization of this in light of the participants in this study, acknowledging both Deardorff's (2004) model and Maslow's (1943) hierarchy of needs (Figure 2) while emphasizing that, in study-abroad programs, participants need health and safety needs taken care of before they can begin to develop intercultural competence.

Participants also reported developments in intercultural attitudes and awareness. Pre-sojourn comments, like the one from Participant 13, expressed concerns about being able to communicate with the tutors because their communication styles may differ. This comment may suggest an awareness that her natural way of communicating may not be conducive to communicating with tutors in Thailand. However, the Japanese university students reported that they were able to interact more effectively with Thai tutor-buddies, especially by having an open and positive attitude towards crosscultural interaction. Some mentioned that being abroad helped them become more active, thus enabling more effective interaction with Thais, which contrasts with more passive attitudes towards cross-cultural interaction back home. As noted earlier, several participants mentioned a heightened curiosity about Asia and other cultures. These attitudes are in line with Deardorff's $(2006,2009)$ model, which suggests that before any other intercultural development can occur, one needs to demonstrate attitudes of curiosity, openness, and respect.

Besides intercultural attitudes, participants mentioned the development of intercultural awareness. As seen earlier, several of them compared their experience in
Thailand with their experience in Japan. Comments from these participants suggest that the knowledge they gained about Japan would not have been possible had they not gone to Thailand. It was their interactions and relationships with tutor-buddies and the local population that made development possible.

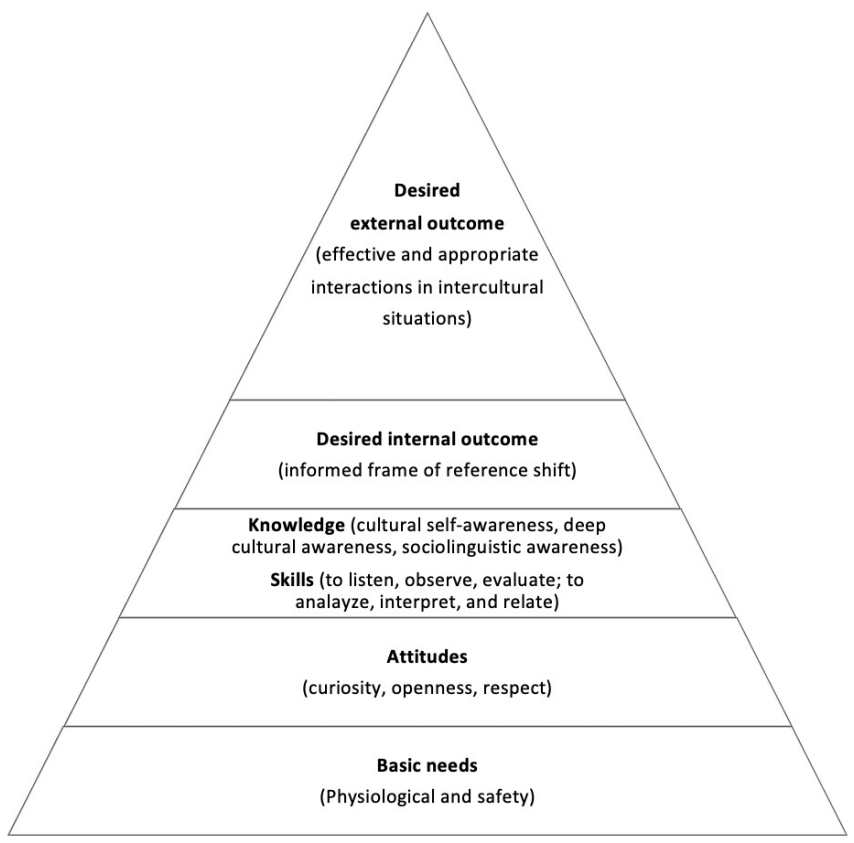

Figure 5. Pyramid of intercultural competence in study-abroad programs. Partially adapted from Maslow's hierarchy of needs.

Relationships were also a common theme. Before departure, participants were both worried and excited about their ability to develop relationships and communicate effectively with their tutor-buddies in Thailand; however, most participants reported positive relationships. They were, for the most part, able to adequately communicate with tutor-buddies and the local population. Participants also referred to their classmates in their reflections, and although most reported that they had built positive relationships with classmates, one did not. She described a feeling of isolation from her group members. It is worth noting that not everyone developed positive relationships 
through these study-abroad experiences. However, as participants' comments suggest, the cultivation of positive relationships with both local students and fellow Japanese participants was an especially important aspect of the short-term program.

There are several implications of this research for those involved in short-term study abroad to consider. First, gathering context-dependent, focused feedback on students' needs can help teachers support sojourners more effectively before, during, and after a program through a deeper understanding of students' perceptions. In addition, Maslow's theory can help to frame the complex interplay of factors, such as the challenges and conditions specific to sojourner needs that relate to intercultural competence development, in a hierarchical manner. For students, becoming more aware of their individual concerns and needs, both before and after sojourning, can allow them to recognize changes in their own attitudes, knowledge, and skills development with respect to health, safety, psychological, and self-fulfillment needs.

\section{Conclusion}

This study of the experiences of Japanese university students who conducted overseas fieldwork and developed their Thai language skills in Thailand has potential implications for other short-term programs. The study suggested in particular that extra care and attention to sojourners' basic needs can lead to further intercultural development, especially in participants' attitudes and knowledge and through their emerging skills of effective interactions and relations with others. If students perceive that their safety and health needs are not being met, opportunities for intercultural development can diminish.

It is worth noting that this study was very limited in scope and cannot be generalized to other short-term overseas programs and their participants. This is particularly true as all participants were female. Research on study abroad by Stemler and Sorkin (2015) and Vande Berg, Connor-Linton, and Paige (2009) posits a gender difference in the development of intercultural competence, with women demonstrating higher levels of intercultural development. In addition, this study examined the experience of students from one ethnic group participating in a short-term program. Both of these demographics, in addition to the sole reliance of the study on qualitative data, are among the several limitations that Brewer, Shively, Gozik, Doyle, and Savicki (2015) called to be addressed in future study-abroad research. Furthermore, we recognize that participants may have answered questions in a manner that they perceived as desirable to others. Vande Berg, Paige, and Lou (2012) encouraged healthy skepticism in response to transformative reports from participants in overseas programs. In future work, we would like to investigate the perspectives of other stakeholders, specifically the Thai participants at the host institution, via a mixed-methods approach.

\section{Acknowledgments}

This work was generously supported by a Nanzan University Pache Research Subsidy I-A2 for the 2019 and 2020 academic years.

\section{Bio Data}

Brad Deacon is an associate professor at Nanzan University in Nagoya, Japan. His research interests include active learning, study abroad, and teacher development. <braddeacon@mac.com>

Kevin J. Ottoson is a language instructor at Nanzan University in Nagoya, Japan. He holds an EdD from the University of New England. His research interests include study abroad and assessment of intercultural competence. <kevinottoson@gmail.com>

\section{References}

Bennett, M. (1986). A developmental approach to training intercultural sensitivity. International Journal of Intercultural Relations, 10(2), 179-186. https://doi.org/10.1016/0147-1767(86)90005-2 Bennett, M. (2013). Basic concepts of intercultural communication: Paradigms, principles, \& practices. Boston, MA: Intercultural Press.

Brewer, E., Shively, R., Gozik, N., Doyle, D., \& Savicki, V. (2015). Beyond the study abroad industry: Perspectives from other disciplines on assessing study abroad learning outcomes. In V. Savicki \& E. Brewer (Eds.)., Assessing study abroad: Theory, tools, and practice (pp. 33-56). Sterling, VA: Stylus.

Charmaz, K. (2014). Constructing grounded theory. Los Angeles, CA: Sage.

Czerwionka, L., Artamonova, T., \& Barbosa, M. (2015). Intercultural knowledge development: Evidence from student interviews during short-term study abroad. International Journal of Intercultural Relations, 49, 80-99. https://doi.org/10.1016/j.ijintrel.2015.06.012

Deardorff, D. K. (2004). The identification and assessment of intercultural competence as a student outcome of international education at institutions of higher education in the United States. [Unpublished doctoral dissertation]. North Carolina State University.

Deardorff, D. K. (2006). The identification and assessment of intercultural competence as a student outcome of internationalization at institutions of higher education in the United States. Journal of Studies in International Education, 10, 241-266. https://doi.org/10.1177/1028315306287002

Deardorff, D. K. (2009). The SAGE handbook of intercultural competence. Thousand Oaks, CA: Sage. 
Deacon \& Ottoson: Intercultural Impact From a Short-Term Study-Abroad Program in Thailand

Deardorff, D. K. (2016). Key theoretical frameworks guiding the scholar-practitioner. In B. Streitweiser \& A. Ogden (Eds.), International higher education's scholar-practitioners: Bridging research and practice (pp. 241-261). Oxford, England: Symposium Books.

Koyanagi, S. (2018). Impact of intercultural communication during short-term study-abroad of Japanese students: Analysis from a perspective of cognitive modification. Journal of Intercultural Communication Research, 47(2), 105-120. https://doi.org/10.1080/17475759.2018.1435423

Lindsay, A. (2014). The gender gap in study abroad. Capstone Collection. (Paper 2734) [Thesis, SIT Graduate Institute]. https://digitalcollections.sit.edu/capstones/2734

Maslow, A. H. (1943). A theory of human motivation. Psychological Review, 50(4), 370-396. http:// dx.doi.org/10.1037/h0054346

Rodriguez, M. T., \& Roberts, T. G. (2011). Identifying best practices for a successful study abroad program. Journal of International Agricultural and Extension Education, 18(1), 19-33. https://doi. org/10.5191/jiaee.2011.18102

Saldaña, J. (2013). The coding manual for qualitative researchers. Los Angeles, CA: Sage.

Spitzberg, B. H., \& Chagnon, G. (2009). Conceptualizing intercultural competence. In D. K. Deardorff (Ed.), The SAGE handbook of intercultural competence (pp. 2-52). Thousand Oaks, CA: Sage.

Stemler, S. E., \& Sorkin, C. K. (2015). A closer look at the Wesleyan intercultural competence scale: A new tool for measuring study abroad outcomes. In V. Savicki \& E. Brewer (Eds.), Assessing study abroad: Theory, tools, and practice (pp. 246-261). Sterling, VA: Stylus.

Strauss, A., \& Corbin, J. (1990). Basics of qualitative research: Grounded theory, procedures, and techniques. Newbury Park, CA: Sage.

Tasci, A. D. A., \& Ko, Y. J. (2015). Travel needs revisited. Journal of Vacation Marketing, 23(1), 20-36. https://doi.org/10.1177/1356766715617499

Vande Berg, M., Connor-Linton, J., \& Paige, M. R. (2009). The Georgetown consortium project: Interventions for student learning abroad. Frontiers: The Interdisciplinary Journal of International Education, 18, 1-75.

Vande Berg, M., Paige, R. M., \& Lou, K. H. (2012). Student learning abroad: Paradigms and assumptions. In M. Vande Berg, R. M. Paige, \& K. H. Lou (Eds.), Student learning abroad: What our students are learning, what they're not, and what we can do about it (pp. 3-28). Sterling, VA: Stylus.

Wingenbach, G. J., Chmielewski, N., Smith, J., Piña, M., \& Hamilton, W. T. (2006). Barriers to international experiential participation. Journal of International Agricultural and Extension Education, 13(3), 79-89. https://doi.org/10.5191/jiaee.2006.13306

\section{Appendix A}

Thai NAP Daily* Schedule Example

\begin{tabular}{ll}
\hline Time & Activity \\
\hline 7:00 8:30 & Breakfast at hotel cafeteria \\
8:40 8:50 & Transfer to KKU from hotel \\
9:00 10:20 & Thai lessons at KKU \\
10:20 10:35 & Coffee and snack break \\
10:35 12:00 & Thai lessons at KKU \\
12:00 12:55 & Lunch at KKU cafeteria (with tutor-buddies) \\
13:00 15:00 & Study Thai with tutor-buddies \\
15:00 & Cultural events, fieldwork preparation, free time \\
\hline
\end{tabular}

Note: Daily* here represents a typical Monday to Friday schedule. Weekends often included cultural daytrips and overnight excursions (accompanied by tutor-buddies and KKU staff).

\section{Appendix B}

Thai NAP Study Abroad Questionnaire

Pre-Thai NAP Study Abroad Questionnaire

1. Why did you choose to participate in Thai NAP, in particular?

2. What concerns or worries do you have now regarding your three-week, study-abroad NAP experience in Thailand?

3. What are your expectations of your three-week, study-abroad NAP experience in Thailand?

\section{Post-Thai NAP Study Abroad Questionnaire}

1. Before going abroad, what were your expectations of your Thai NAP experience? Were those expectations met? Why (not)?

2. Before going abroad, what were some of your concerns or worries about your Thai NAP experience? Did they happen? If they did, how did you cope? 
3. What meaningful experiences did you have while you were abroad during Thai NAP? What did you learn from these experiences?

4. What advice would you give to the next group of Thai NAP participants to get ready for their trip abroad?

5. Looking back on your Thai NAP experience, do you feel you experienced a change as a person, or not? Why or why not? Please explain.

6. If there is anything else that you would like to share about your Thai NAP experience, please share it. 